\title{
Potencial Herbicida da Biomassa e de Substâncias Químicas Produzidas Pelo Fungo Endofítico Pestalotiopsis guepinii ${ }^{1}$
}

\author{
Herbicide Potential of the Biomass and Chemical Compounds Produced by the Fungus \\ Pestalotiopsis guepinii
}

\author{
SANTOS, L.S. ${ }^{2}$, OLIVEIRA, M.N. ${ }^{2}$, GUILHON, G.M.S.P. ${ }^{2}$, SANTOS, A.S. ${ }^{2}$,FERREIRA, I.C.S. ${ }^{2}$, \\ LOPES-JÚNIOR, M.L. ${ }^{2}$, ARRUDA, M.S.P. ${ }^{2}$, SAILVA, M.N. ${ }^{2}$, SOUZA FILHO, A.P.S. ${ }^{3}$, RODRIGUES- \\ FILHO, E. ${ }^{4}$ e OLIVEIRA, M.C.F ${ }^{5}$.
}

\begin{abstract}
RESUMO - Muitas substâncias químicas disponiveis na natureza, produzidas por plantas ou por microrganismos, podem oferecer novas e excelentes oportunidades para diversificar o controle de pragas na agricultura e na prática agrícola, e, nesse sentido, os fungos podem contribuir de forma positiva. O objetivo deste trabalho foi caracterizar o potencial inibitório na germinação de sementes e no desenvolvimento de plântulas de duas espécies de plantas daninhas em relação aos extratos e substâncias químicas obtidas da biomassa produzida por Pestalotiopsis guepinii - um fungo endofitico da espécie Virola michelii. Foram desenvolvidos bioensaios em condições controladas de $25^{\circ} \mathrm{C}$ e fotoperíodo de 12 horas, para germinação, e de $25{ }^{\circ} \mathrm{C}$ e fotoperíodo de 24 horas, para desenvolvimento da radícula e do hipocótilo. Os extratos brutos foram analisados em concentração de $1,0 \%(\mathrm{~m} / \mathrm{v})$. Os resultados indicaram

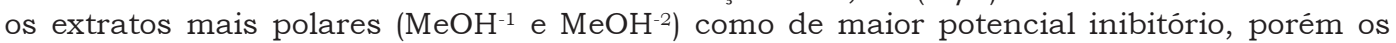
efeitos promovidos pelos extratos hexânicos e acetato de etila foram expressivos, especialmente em relação à germinação das sementes. Comparativamente, a germinação das sementes das espécies de plantas daninhas se mostrou mais sensivel aos efeitos do que o desenvolvimento das plântulas. Das espécies receptoras, Mimosa pudica (malícia) apresentou maior sensibilidade aos efeitos inibitórios dos extratos. Entretanto, na germinação de sementes da espécie Senna obtusifolia (mata-pasto), o extrato MeOH-1 apresentou $100 \%$ de inibição. As substâncias ergosterol e peróxido de ergosterol, isoladas do extrato hexânico, quando testadas isoladamente, apresentaram potencial inibitório sempre abaixo dos 35\%, não repetindo o potencial inibitório do extrato hexânico, de onde foram isoladas. Quando testadas juntas, não se verificaram aumentos expressivos na atividade herbicida, embora acréscimos na atividade inibitória tenham sido observados.
\end{abstract}

Palavras-chave: germinação, hipocótilo, inibição, radícula, sementes, Virola michelii, Mimosa pudica, Senna obtusifolia.

\begin{abstract}
Many of the chemical compounds found in nature that are produced by plants or microorganisms can offer new and efficient ways of controlling pests in agriculture and agricultural practice, with the help of fungi. The objective of this work is to characterize the inhibitory potential for seed germination and the plantlet development of two weed species using extracts and compounds obtained from biomass produced by Pestalotiopsis guepinii, an endophytic fungus of the species Virola michelii. The bioassays were developed under controlled conditions at $25^{\circ} \mathrm{C}$ and 12 hour photoperiod for germination, and at $25^{\circ} \mathrm{C}$ and 12-hour photoperiod for root and hypocotyl development. The crude extracts were analyzed at a concentration of $1.0 \%(\mathrm{~m} / \mathrm{v})$. The results showed that the more polar extracts $\left(\mathrm{MeOH}^{-1}\right.$ and $\left.\mathrm{MeOH}^{-2}\right)$ have the highest inhibitory potential, although the hexane and ethyl acetate extract effects were important, especially for seed germination. Comparatively, weed seed germination was more sensitive to the effects than plantlet development.
\end{abstract}

1 Recebido para publicação em 4.8.2007 e na forma reformulada em 12.3.2008.

2 Universidade Federal do Pará, Rua Augusto Corrêa, 01. 66075-900, Belém, Pará; ${ }^{3}$ Embrapa Amazônia Oriental, Trav. Dr. Enéas Pinheiro, s/n. 66095-100, Belém, Pará; ${ }^{4}$ Dep. de Química, Universidade Federal de São Carlos, Caixa Postal 676, 13565-905, São Carlos-SP, ${ }^{5}$ Dep. de Química Orgânica e Inorgânica, Universidade Federal do Ceará, 60455-970, Fortaleza-CE. 


\begin{abstract}
Mimosa pudica was more affected by the inhibitory effects of the extracts. However, for seed germination of Senna obtusifolia, the extract $\mathrm{MeOH}-1$ showed $100 \%$ inhibition. The compounds ergosterol and ergosterol peroxide showed an inhibitory potential always below 35\%, not showing the in hibitory potential of the hexane extract from which they were isolated. When these compounds were tested together, little increase was observed in the inhibitory activity.
\end{abstract}

Keywords: germination, hypocotyl, inhibition, root, seeds, Virola michelii; Mimosa pudica; Senna obtusifolia

\section{INTRODUÇÃO}

Nos últimos anos, tem crescido a preocupação da sociedade em preservar o ambiente. Dentre os vários fatores inerentes a essa preocupação, destaca-se o uso de inseticidas, fungicidas, acaricidas e herbicidas que apresentam potencial de comprometer a qualidade do ambiente e da saúde humana. Um grande número de metabólitos primários e secundários disponiveis na natureza, sejam eles produzidos por plantas ou por microrganismos, podem oferecer novas e excelentes oportunidades para diversificar o controle de pragas na agricultura, reduzindo ou eliminando a contaminação do ambiente e, conseqüentemente, preservando os recursos naturais e garantindo o oferecimento de produtos agrícolas com qualidade adequada para a alimentação (Souza Filho \& Alves, 2002).

O Brasil detém cerca de $20 \%$ da biodiversidade mundial, principalmente na floresta amazônica, a maior do planeta e fonte inestimável de matérias-primas nos mais variados setores. Apesar da imensa diversidade biológica, as espécies que a compõem e suas relações filogenéticas são pouco conhecidas, principalmente os microrganismos e suas interações com outros seres vivos (Souza et al., 2004).

Uma grande parcela dos microrganismos, em especial os fungos, habita o interior das plantas. São os chamados fungos endofiticos, que colonizam os tecidos sadios das plantas, em algum tempo do seu ciclo de vida, sem lhes causar danos aparentes (Petrini, 1991).

Os endofíticos são potencialmente úteis na agricultura e na indústria, podendo ser utilizados como vetores para introdução de genes de interesse nas plantas (Fahey, 1998; Murray et al., 1992), como agente inibidores de pragas e patógenos (Volksch et al., 1992; Hallmann \&
Sikora, 1996) e como fonte de metabólitos primários e secundários de interesse (Marinho et al., 2005a, b). Os fungos endofiticos produzem substâncias com atividades do tipo fungicida, herbicida e algicida, entre outras (Santos, 2001).

A química de microorganismos endofiticos tem sido muito pouco estudada, se considerada a vasta biodiversidade fúngica e a especificidade nas colonizações das plantas hospedeiras por fungos. O estudo dessas interações entre plantas e microrganismos, além de contribuir grandemente para o entendimento de muitos processos químicos na natureza e na ecologia, pode resultar no estabelecimento de fontes alternativas de substâncias de interesse para a humanidade.

Nesse contexto, pretende-se contribuir na busca de substâncias que possam servir de protótipo para elaboração de bioerbicidas e para conhecimento da diversidade dos microrganismos da Amazônia, em especial do fungo endofitico Pestalotiopsis guepinii isolado das folhas de Virola michelli.

A espécie $V$. michelli é pertencente à família Myristicaceae, morfologicamente considerada uma das mais primitivas Angiospermas. Diversas atividades farmacológicas são atribuídas às plantas dessa família, principalmente aquelas pertencentes aos gêneros nativos do continente americano, sendo o gênero Virola o que mais tem contribuído. É, também, utilizada na medicina popular como emplasto para alivio de irritações causadas por fungos e no tratamento de infecções da pele (Gottlieb \& Yoshida, 1984).

Algumas das espécies de Pestalotiopsis têm chamado muita atenção por produzir metabólitos secundários importantes, como o diterpenóide taxol, uma importante droga 
anticancerigena produzida por Pestalotiopsis guepinii isolado de Wollemia nobilis (Summerel et al., 1998), assim como outras atividades, do tipo fitotóxica, antifúngica e antioxidante (Strobel et al., 2002).

Estudos fitoquímico (Santos et al., 1996) e farmacológico (Carvalho et al., 1999) têm demonstrado o potencial antiinflamatório de extratos brutos e de substâncias isoladas das folhas de $V$. michelii. Recentemente, extratos e substâncias isoladas das folhas de $V$. michelii apresentaram potencial alelopático significativo em relação a plantas invasoras de pastagens (Souza Filho et al., 2006; Santos et al., 2007).

Este trabalho teve como objetivo caracterizar o potencial inibitório da biomassa e de substâncias químicas produzidas pelo fungo endofitico Pestalotiopsis guepinii, isolado das folhas de $V$. michelii, sobre a germinação das sementes e o desenvolvimento da radícula e do hipocótilo de duas espécies de plantas daninhas.

\section{MATERIAL E MÉTODOS}

\section{Coleta e preparo do material botânico}

As folhas jovens de Virola michelii foram coletadas no Campo Experimental da Embrapa Amazônia Oriental, localizado no município de Belém, Estado do Pará, sendo a identificação botânica realizada no Laboratório de Botânica da mesma instituição, em cujo herbário encontra-se depositada uma exsicata sob o número de registro 180621 .

\section{Esterilização do material vegetal e isolamento dos endofiticos}

O material botânico coletado foi processado no laboratório de produtos naturais da Universidade Federal do Pará, dentro de quatro horas após a coleta. Foi lavado abundantemente com água corrente e detergente neutro, para retirar o excesso de epifiticos. Em seguida, em câmara asséptica, o material foi imerso em álcool $70 \%$ por um minuto, em hipoclorito de sódio 3\% por quatro minutos e novamente em álcool $70 \%$ por 30 segundos. Finalmente, o material foi lavado com água destilada (Pereira, 1993).

Após a assepsia, pequenos fragmentos foram plaqueados em meio de batata, dextrose e ágar (BDA), com 0,2\% de extrato de levedura acrescido de terramicina $\left(1 \mathrm{mg} \mathrm{mL}^{-1}\right)$, para inibir o crescimento bacteriano no decorrer do processo de isolamento dos fungos endofiticos. As placas de Petri, contendo os fragmentos, foram incubadas a $25^{\circ} \mathrm{C}$.

A partir do sétimo dia de incubação, pequenos fragmentos de BDA com hifas dos fungos recém-desenvolvidos foram transferidos para outras placas contendo meio BDA. Esse procedimento foi repetido por período de sete dias.

Após o isolamento dos endófitos, a purificação foi feita pela técnica de repiques sucessivos. Os endofiticos isolados foram armazenados em duplicata, conforme metodologia descrita por Castellani (1939).

Dentre as 26 linhagens de endofiticos isolados, foi escolhido, para cultivo em grande escala, o fungo Pestalotiopsis guepinii para obtenção de sua biomassa e realização do estudo com vista ao isolamento, identificação de substâncias químicas e estudos de atividade herbicida. O endofitico P.guepinii foi escolhido para realização deste trabalho por excretar macroscopicamente um exsudato - fato este não observado nas demais linhagens isoladas.

\section{Cultivo em cereal (arroz)}

Em cada erlenmeyer de $500 \mathrm{~mL}$ foram adicionados $100 \mathrm{~g}$ do cereal (arroz), totalizando 40 erlenmayers; em seguida, adicionaram-se $30 \mathrm{~mL}$ de água destilada. Esse meio foi autoclavado por 45 minutos à temperatura de $121{ }^{\circ} \mathrm{C}$. Após atingir a temperatura ambiente em câmara asséptica, foram adicionados nos erlenmeyers fragmentos do fungo desenvolvido em BDA, posteriormente incubados a $25^{\circ} \mathrm{C}$, por 30 dias.

\section{Obtenção dos extratos}

Após o período de incubação, foram acrescentados aproximadamente $400 \mathrm{~mL}$ de metanol por erlenmeyers, ficando o sistema em repouso por cinco horas. O metanol, por ser tóxico, destrói os esporos, o que evita o risco de contaminação durante o manuseio da amostra. O sistema foi filtrado com o auxílio de fraldas de algodão e o extrato metanólico obtido foi concentrado em evaporador rotativo, fornecendo o extrato metanólico ${ }^{-1}\left(\mathrm{MeOH}^{-1}\right)$. 
Após a filtração, o cereal foi seco em estufa a $45^{\circ} \mathrm{C}$ e, em seguida, submetido à extração por percolação com hexano, acetato de etila e metanol, fornecendo, respectivamente, os extratos hexânico, acetato de etila (AcOEt) e metanólico ${ }^{-2}\left(\mathrm{MeOH}^{-2}\right)$. A obtenção dos extratos é descrita na Figura 1 e o fluxograma da Figura 2 descreve o processo de isolamento das duas substâncias.

\section{Isolamento das substâncias ergosterol e peróxido de ergosterol}

As substâncias ergosterol (1) e peróxido de ergosterol (2) (Figura 3) foram isoladas a partir de 9,0 g do extrato hexânico obtido da extração por percolação do meio sólido (arroz). Esse extrato consistiu de duas fases: uma liquida e uma sólida. O sólido foi separado por filtração, e os cristais resultantes foram analisados através de técnicas uni e bidimensionais de RMN ${ }^{1} \mathrm{H}$ e ${ }^{13} \mathrm{C}$, o que levou à identificação do esteróide ergosterol (1). A fase líquida (filtrado hexânico) foi fracionada em coluna cromatográfica de sílica-gel, com o sistema de eluentes em gradiente crescente de polaridade com hexano e acetato de etila (AcOEt). Todas as frações originadas do fracionamento da fase líquida do extrato hexânico foram submetidas à análise por $\mathrm{RMN}{ }^{1} \mathrm{H}$ e ${ }^{13} \mathrm{C}$ unidimensional. A fração hex/AcOEt $60 \%$, por apresentar sinais de hidrogênios aromáticos no espectro de $\mathrm{RMN}{ }^{1} \mathrm{H}$, foi trabalhada da seguinte maneira: submeteu-se a fração à análise por Cromatografia Líquida de Alta Eficiência (CLAE) no modo gradiente, para obtenção de seu perfil cromatográfico; para esta análise cromatográfica, foi utilizada uma coluna $(250 \mathrm{~mm}$ $\mathrm{x}$ 4,60 $\mathrm{mm}$ ) Synergi Fusion com fase estacionária $\mathrm{C} 18$ da Phenomenex, fase móvel composta $\mathrm{H}_{2} \mathrm{O}: \mathrm{MeCN}$, variando B de 5 a $100 \%$ em 60 minutos, o tempo do gradiente, fluxo de

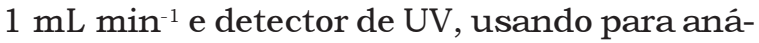
lise o comprimento de onda de $215 \mathrm{~nm}$. A partir da análise do cromatograma obtido, utilizouse um cartucho analítico seguido de um preparativo, obtendo-se duas frações e o peróxido de ergosterol (2).

\section{Bioensaios dos extratos}

Os extratos hexânico, acetato de etila e metanólico-2, obtidos a partir do processo de extração por percolação do arroz, assim como o extrato metanólico-1, obtido do processo de eliminação do fungo Pestalotiopsis guepinii, foram submetidos aos bioensaios na concentração de $1 \%(\mathrm{~m} / \mathrm{v})$, para as espécies de plantas daninhas Senna obtusifolia (mata-pasto) e Mimosa pudica (malicia) - duas importantes espécies de plantas daninhas que infestam as áreas de pastagens cultivadas da região amazônica - utilizando, como testemunha, água destilada.

\section{Bioensaio de germinação de sementes}

Foi realizado em condições controladas de $25{ }^{\circ} \mathrm{C}$ de temperatura constante e fotoperíodo de 12 horas. A germinação foi monitorada em período de cinco dias, com contagens diárias e eliminação das sementes germinadas. Consideraram-se sementes germinadas aquelas que apresentavam extensão radicular igual ou superior a 2,0 $\mathrm{mm}$. Para cada placa de Petri de 9,0 cm de diâmetro, forrada com uma folha de papel-filtro qualitativo, colocaram-se 10 sementes.

\section{Bioensaio de desenvolvimento da radicula e do hipocótilo}

Esses bioensaios também foram desenvolvidos em condições controladas de $25^{\circ} \mathrm{C}$ de temperatura e fotoperiodo de 24 horas. Cada placa de Petri de $9,0 \mathrm{~cm}$ de diâmetro, forrada com uma folha de papel-filtro qualitativo, recebeu quatro sementes pré-germinadas. Ao final de 10 dias de crescimento, foi medido o comprimento da radícula e do hipocótilo.

Em todos os bioensaios, cada placa de Petri recebeu 3,0 $\mathrm{mL}$ do extrato $(1 \% \mathrm{~m} / \mathrm{v})$. Após evaporação do solvente, adicionou-se igual volume de água destilada, mantendo-se, dessa forma, a concentração original. Os extratos foram adicionados apenas uma vez, quando do início do bioensaio, sendo a partir de então adicionada apenas água destilada, sempre que se fazia necessário.

As sementes das plantas daninhas foram coletadas em áreas de pastagens cultivadas no município de Castanhal, Estado do Pará. Elas passaram por um processo de limpeza e expurgo e foram tratadas com vista à quebra de dormência (Souza Filho et al., 1998). 


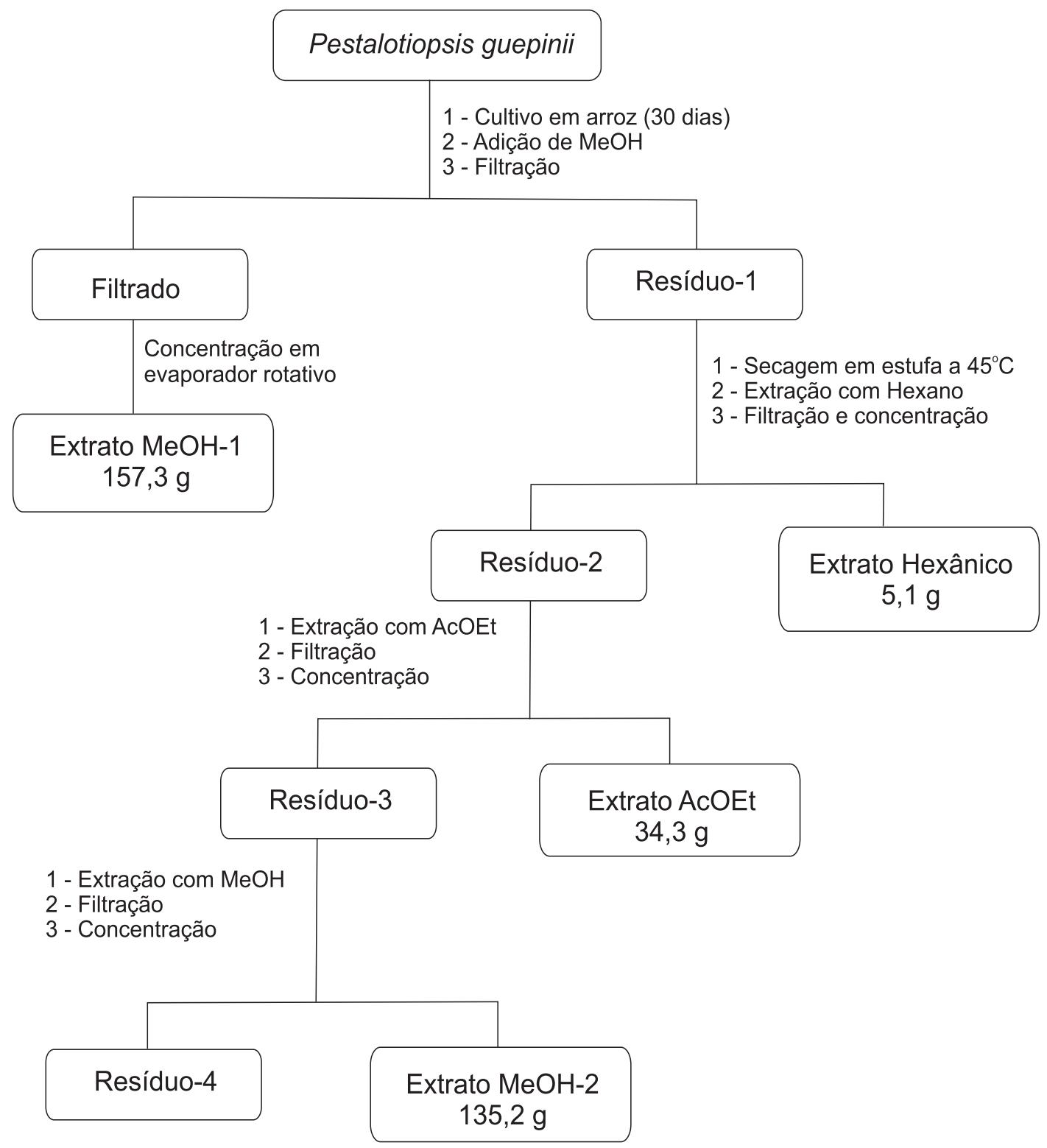

Figura 1 - Fluxograma de obtenção dos extratos da biomassa produzida por P. guepinii.

\section{Bioensaios das substâncias isoladas}

As substâncias ergosterol (1) e peróxido de ergosterol (2), isoladas do extrato hexânico obtido do meio sólido (arroz), após serem purificadas, foram submetidas aos bioensaios nas concentrações de: ergosterol 20, 80 e 200 ppm e peróxido de ergosterol 200 ppm, usando como solvente o clorofórmio e utilizando como testemunha água destilada, em relação às espécies invasoras de pastagens Senna obtusifolia (mata-pasto) e Mimosa pudica (malícia). O clorofórmio é utilizado apenas como solvente; em seguida é evaporado, não interferindo nos testes.

Os bioensaios foram realizados à seme1hança daqueles em que se avaliaram os efeitos dos extratos brutos, utilizando-se as mesmas temperaturas e fotoperíodo empregados 


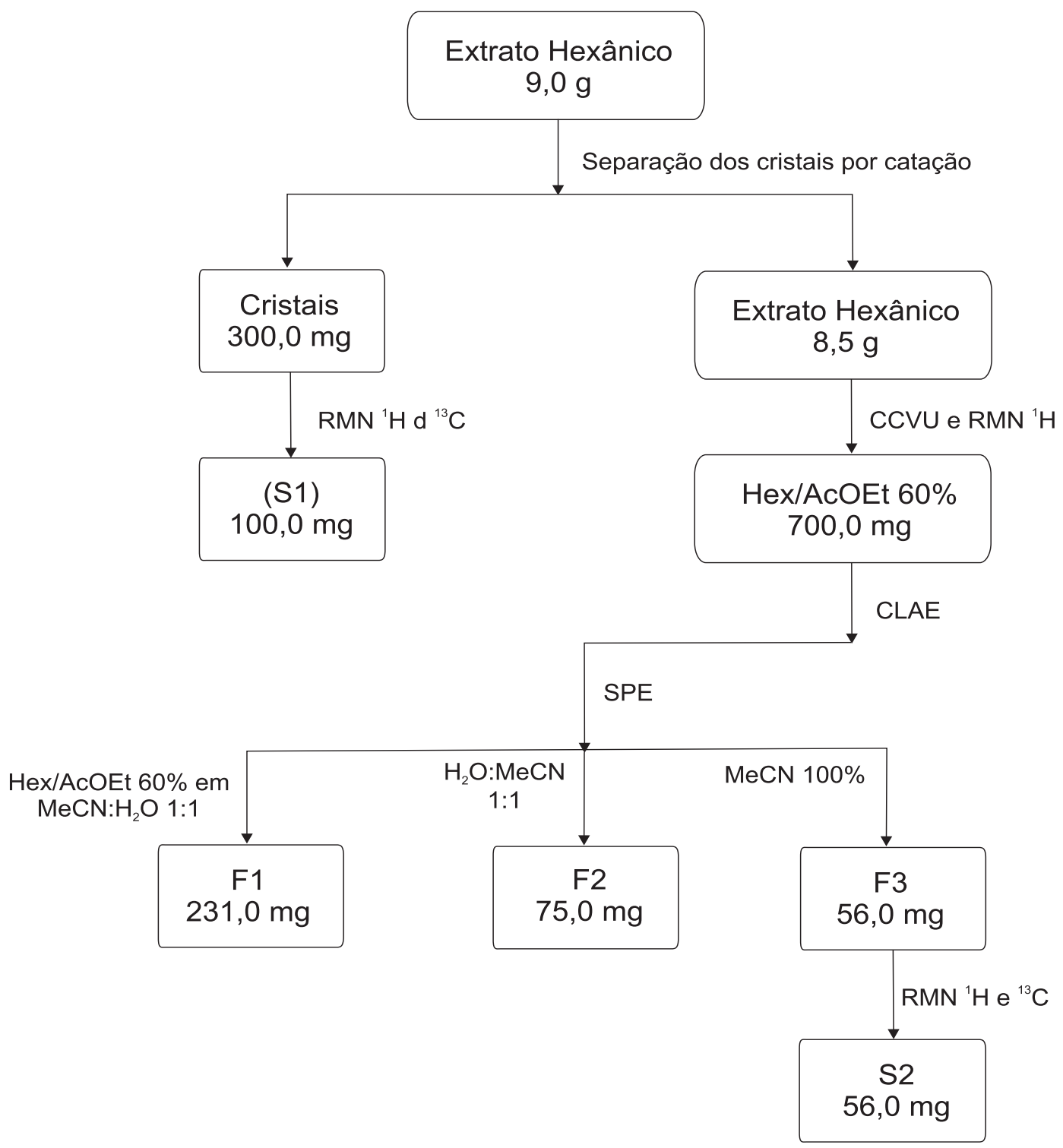

Figura 2 - Fluxograma do isolamento do ergosterol (1) e do peróxido de ergosterol (2)

tanto para a germinação quanto para o desenvolvimento da radícula e do hipocótilo. Para a germinação de sementes, a diferença ficou por conta do número de sementes, que no presente caso foi de 30 sementes por placa de Petri; para o desenvolvimento das plântulas, foram empregadas duas sementes pré-germinadas.

Na concentração de 200 ppm, além dos bioensaios com as substâncias isoladas, foram realizados bioensaios com as substâncias em mistura (em par): 200 ppm de cada substância.
Cada placa de Petri recebeu $3,0 \mathrm{~mL}$ da solução de 1 e $3,0 \mathrm{~mL}$ da solução de 2 . O ensaio foi realizado no período de cinco dias e nas mesmas condições anteriormente descritas, visando a inibição do desenvolvimento da radícula e do hipocótilo.

\section{RESULTADOS E DISCUSSÃO}

Nos testes envolvendo a utilização de extratos brutos, os efeitos inibitórios variaram 


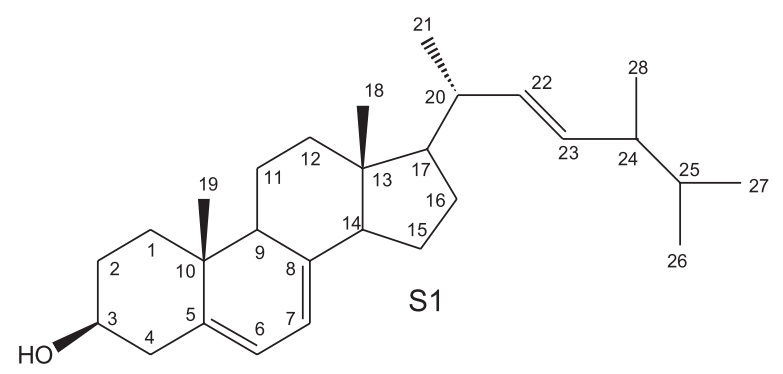

de acordo com a literatura (Shimada et al., 2003), justificaria a elevada atividade desses extratos. As Tabelas 1 a 3 exibem os resultados obtidos.

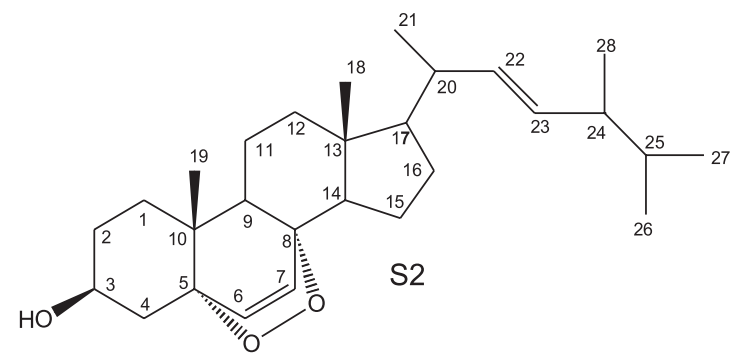

Tabela 1 - Efeitos potencialmente alelopáticos de extratos brutos $(1 \% \mathrm{~m} / \mathrm{v})$ obtidos a partir da biomassa do fungo endofítico P. guepinii sobre a germinação de sementes de plantas daninhas. Dados expressos em percentual de inibição, em relação ao tratamento testemunha, água destilada

\begin{tabular}{|c|c|c|}
\hline \multirow{2}{*}{ Extrato testado } & \multicolumn{2}{|c|}{ Planta receptora } \\
\cline { 2 - 3 } & Malícia & Mata-pasto \\
\hline Hexânico & $34,0 \mathrm{Cb}$ & $66,0 \mathrm{Ba}$ \\
\hline AcOEt & $14,0 \mathrm{Db}$ & $66,0 \mathrm{Ba}$ \\
\hline $\mathrm{MeOH}-1$ & $94,0 \mathrm{Ab}$ & $100,0 \mathrm{Aa}$ \\
\hline $\mathrm{MeOH}-2$ & $80,0 \mathrm{Ba}$ & $67,0 \mathrm{Bb}$ \\
\hline
\end{tabular}

Figura 3 - Estruturas do ergosterol (1) e do peróxido de ergosterol (2) isolados da biomassa produzida por Pestalotiopsis guepinii

em função da polaridade do extrato, da espécie receptora e do fator das plantas receptoras analisado. Os extratos $\mathrm{MeOH}^{-1}$ e $\mathrm{MeOH}^{-2}$ apresentaram maior potencial inibitório da germinação e do desenvolvimento da radícula e do hipocótilo das plantas daninhas malícia e mata-pasto. Para a espécie malícia, os extratos $\mathrm{MeOH}^{-1} \mathrm{e} \mathrm{MeOH}^{-2}$ inibiram a germinação em 94 e $80 \%$, respectivamente; e para a espécie mata-pasto, em 100 e $67 \%$, respectivamente. No bioensaio de desenvolvimento da radícula, os extratos $\mathrm{MeOH}^{-1}$ e $\mathrm{MeOH}^{-2}$ apresentaram, respectivamente, 49 e $48 \%$ de inibição para a espécie malícia e 51 e $58 \%$, respectivamente, para a espécie mata-pasto. Em relação à inibição do desenvolvimento do hipocótilo, frente à espécie malícia, os extratos $\mathrm{MeOH}^{-1}$ e $\mathrm{MeOH}^{-2}$ apresentaram, respectivamente, 55 e $51 \%$ de inibição e, para a espécie mata-pasto, 48 e $43 \%$. Esses dados indicam que, das espécies receptoras, no conjunto de resultados obtidos, a espécie invasora malícia apresentou maior sensibilidade aos efeitos inibitórios dos extratos. Entretanto, na germinação de sementes da espécie mata-pasto, o extrato $\mathrm{MeOH}^{-1}$ apresentou $100 \%$ de inibição. Estudos por cromatografia líquida de alta eficiência e análises por RMN de ${ }^{1} \mathrm{H}$ e de ${ }^{13} \mathrm{C}$ dos extratos metanólicos indicam tratar-se de misturas de antraquinonas, o que,

Médias seguidas de letras iguais, maiúsculas na coluna e minúsculas na linha, não diferem pelo teste de Tukey (5\%).

Tabela 2 - Efeitos potencialmente alelopáticos de extratos brutos $(1 \% \mathrm{~m} / \mathrm{v})$ obtidos a partir da biomassa do fungo endofítico P. guepinii sobre o desenvolvimento da radícula de plantas daninhas. Dados expressos em percentual de inibição, em relação ao tratamento testemunha água destilada

\begin{tabular}{|c|c|c|}
\hline \multirow{2}{*}{ Extrato testado } & \multicolumn{2}{|c|}{ Planta receptora } \\
\cline { 2 - 3 } & Malícia & Mata-pasto \\
\hline Hexânico & $18,0 \mathrm{Ca}$ & $7,0 \mathrm{Db}$ \\
\hline AcOEt & $44,0 \mathrm{Ba}$ & $12,0 \mathrm{Cb}$ \\
\hline $\mathrm{MeOH}-1$ & $49,0 \mathrm{Aa}$ & $51,0 \mathrm{Aa}$ \\
\hline $\mathrm{MeOH}-2$ & $48,0 \mathrm{Aa}$ & $38,0 \mathrm{Bb}$ \\
\hline
\end{tabular}

Médias seguidas de letras iguais, maiúsculas na coluna e minúsculas na linha, não diferem pelo teste de Tukey (5\%).

Tabela 3 -Efeitos potencialmente alelopáticos de extratos brutos $(1 \% \mathrm{~m} / \mathrm{v})$ obtidos a partir da biomassa do fungo endofítico $P$. guepinii sobre o desenvolvimento do hipocótilo de plantas daninhas. Dados expressos em percentual de inibição, em relação ao tratamento testemunha água destilada

\begin{tabular}{|c|c|c|}
\hline \multirow{2}{*}{ Extrato testado } & \multicolumn{2}{|c|}{ Planta receptora } \\
\cline { 2 - 3 } & Malícia & Mata-pasto \\
\hline Hexânico & $35,0 \mathrm{Ca}$ & $3,0 \mathrm{Db}$ \\
\hline AcOEt & $51,0 \mathrm{Ba}$ & $24,0 \mathrm{Cb}$ \\
\hline $\mathrm{MeOH}-1$ & $55,0 \mathrm{Aa}$ & $48,0 \mathrm{Ab}$ \\
\hline $\mathrm{MeOH}-2$ & $51,0 \mathrm{Ba}$ & $43,0 \mathrm{Bb}$ \\
\hline
\end{tabular}

Médias seguidas de letras iguais, maiúsculas na coluna e minúsculas na linha, não diferem pelo teste de Tukey (5\%). 
Embora em menor magnitude, os extratos apolares (hexânico) e de polaridade intermediária (acetato de etila) também apresentaram potencial para inibir os fatores das plantas analisados, com destaque para os efeitos inibitórios promovidos sobre a germinação de sementes da espécie mata-pasto, com $66,0 \%$ de inibição efetivado pelos dois extratos (Tabela 1). Quanto aos efeitos verificados sobre o desenvolvimento da radícula (Tabela 2) e do hipocótilo (Tabela 3), o extrato bruto acetato de etila tendeu a promover inibição de maior magnitude, tanto para malícia como para mata-pasto.

Embora o extrato bruto hexânico tenha apresentado potencial inibitório inferior ao dos extratos mais polares, ele apresentou-se mais puro; a partir dele foram isolados o ergosterol (1) e o peróxido de ergosterol (2) em quantidade suficiente para a realização dos bioensaios.

Os bioensaios com o ergosterol (1) e com o peróxido de ergosterol (2) isoladamente ou em associação, promoveram inibições que não ultrapassaram $32,5 \%$, bem abaixo dos efeitos promovidos pelo extrato bruto hexânico, embora aqui se deva considerar a concentração das substâncias puras (na ordem de ppm) e a dos extratos (na ordem de 1,0\% m/v). A substância 1 , testada para a espécie malícia, indicou percentual de inibição de apenas 3 e 19\% nas concentrações de 20 e 80 ppm, respectivamente, no teste de inibição da germinação (Tabela 4). Em relação à espécie mata-pasto, os efeitos estiveram bem próximos, com 3 e $16 \%$, respectivamente para as duas concentrações. Nos estudos envolvendo o desenvolvimento da radícula (Tabela 5) foram usadas soluções nas concentrações de 20, 80 e 200 ppm, levando a um percentual de inibição de 5,8, 8,6 e $11,7 \%$ sobre a espécie malícia e de 0,1 e $32,5 \%$ sobre mata-pasto, respectivamente.

Os efeitos verificados sobre o desenvolvimento do hipocótilo (Tabela 6) indicaram percentuais de inibição da ordem de 0,1 e $3 \%$ para a espécie malícia e de apenas 1, 1 e 1\% para mata-pasto, respectivamente para as mesmas concentrações (20, 80 e 200 ppm).

A substância 2, por ser isolada em menor quantidade, foi testada somente na concentração de 200 ppm. Visando a inibição da germinação das sementes e o desenvolvimento da radícula e do hipocótilo da espécie malícia, os
Tabela 4 - Efeitos do ergosterol (1) sobre a germinação de sementes de duas plantas daninhas. Dados expressos em percentual de inibição, em relação ao tratamento testemunha água destilada

\begin{tabular}{|c|c|c|}
\hline \multirow{2}{*}{$\begin{array}{c}\text { Concentração } \\
(\mathrm{ppm})\end{array}$} & \multicolumn{2}{|c|}{ Planta daninha } \\
\cline { 2 - 3 } & Malícia & Mata-pasto \\
\hline 20 & $3,0 \mathrm{Ba}$ & $3,0 \mathrm{Ba}$ \\
\hline 80 & $19,0 \mathrm{Aa}$ & $16,0 \mathrm{Ab}$ \\
\hline
\end{tabular}

Médias seguidas de letras iguais, maiúsculas na coluna e minúsculas na linha, não diferem pelo teste de Tukey (5\%).

Tabela 5 - Efeitos do ergosterol (1) sobre o desenvolvimento da radícula de duas plantas daninhas. Dados expressos em percentual de inibição, em relação ao tratamento testemunha água destilada

\begin{tabular}{|c|c|c|}
\hline \multirow{2}{*}{$\begin{array}{c}\text { Concentração } \\
(\mathrm{ppm})\end{array}$} & \multicolumn{2}{|c|}{ Planta daninha } \\
\cline { 2 - 3 } & Malícia & Mata-pasto \\
\hline 20 & $5,8 \mathrm{Ba}$ & $0,0 \mathrm{Bb}$ \\
\hline 80 & $8,6 \mathrm{Aa}$ & $1,0 \mathrm{Ba}$ \\
\hline 200 & $11,7 \mathrm{Ab}$ & $32,5 \mathrm{Aa}$ \\
\hline
\end{tabular}

Médias seguidas de letras iguais, maiúsculas na coluna e minúsculas na linha, não diferem pelo teste de Tukey (5\%).

Tabela 6 - Efeitos do ergosterol (1) sobre o desenvolvimento do hipocótilo de duas plantas daninhas. Dados expressos em percentual de inibição, em relação ao tratamento testemunha água destilada

\begin{tabular}{|c|c|c|}
\hline \multirow{2}{*}{$\begin{array}{c}\text { Concentração } \\
(\text { ppm })\end{array}$} & \multicolumn{2}{|c|}{ Planta daninha } \\
\cline { 2 - 3 } & Malícia & Mata-pasto \\
\hline 20 & 1,0 & 1,0 \\
\hline 80 & 3,0 & 1,0 \\
\hline 200 & 1,0 & 1,0 \\
\hline
\end{tabular}

Médias seguidas de letras iguais, maiúsculas na coluna e minúsculas na linha, não diferem pelo teste de Tukey (5\%).

potenciais obtidos foram de 4, 11,7 e 3\%, respectivamente; para a espécie mata-pasto, os percentuais de inibição foram de 14, 1 e 1\%, para inibição da germinação e desenvolvimento da radícula e do hipocótilo, respectivamente.

Apesar dos baixos percentuais inibitórios apresentados pelas substâncias 1 e 2, quando testadas isoladamente, nos bioensaios em mistura 1:1 das substâncias (na concentração de 200 ppm de cada substância), para a espécie malicia, houve inibição do desenvolvimento da radícula da ordem de $22 \%$ e do hipocótilo de $13 \%$ (Tabelas 7 e 8). Já para a espécie mata- 
Tabela 7 - Efeitos do ergosterol (1) (200 ppm), peróxido de ergosterol (2) (200 ppm) e mistura de $1(200 \mathrm{ppm})+2$ (200 ppm) sobre o desenvolvimento da radícula de duas plantas daninhas. Dados expressos em percentual de inibição, em relação ao tratamento testemunha água destilada

\begin{tabular}{|c|c|c|}
\hline \multirow{2}{*}{ Substância } & \multicolumn{2}{|c|}{ Planta daninha } \\
\cline { 2 - 3 } & Malícia & Mata-pasto \\
\hline Ergosterol & $11,7 \mathrm{Bb}$ & $32,5 \mathrm{Aa}$ \\
\hline Peróxido de Ergosterol & $11,7 \mathrm{Ba}$ & $1,0 \mathrm{Cb}$ \\
\hline Ergosterol + Peróxido & $22,0 \mathrm{Ab}$ & $27,5 \mathrm{Ba}$ \\
\hline
\end{tabular}

Médias seguidas de letras iguais, maiúsculas na coluna e minúsculas na linha, não diferem pelo teste de Tukey (5\%).

Tabela 8 - Efeitos do ergosterol (1) (200 ppm), peróxido de ergosterol (2) (200 ppm) e mistura de $1(200 \mathrm{ppm})+2$ (200 ppm) sobre o desenvolvimento do hipocótilo de duas plantas daninhas. Dados expressos em percentual de inibição, em relação ao tratamento testemunha água destilada

\begin{tabular}{|c|c|c|}
\hline \multirow{2}{*}{ Substância } & \multicolumn{2}{|c|}{ Planta daninha } \\
\cline { 2 - 3 } & Malícia & Mata-pasto \\
\hline Ergosterol & $10,0 \mathrm{Ba}$ & $1,0 \mathrm{Ba}$ \\
\hline Peróxido de Ergosterol & $3,0 \mathrm{Ca}$ & $1,0 \mathrm{Ba}$ \\
\hline Ergosterol + Peróxido & $13,0 \mathrm{Aa}$ & $10,0 \mathrm{Ab}$ \\
\hline
\end{tabular}

Médias seguidas de letras iguais, maiúsculas na coluna e minúsculas na linha, não diferem pelo teste de Tukey (5\%).

pasto o percentual de inibição da mistura para o desenvolvimento da radícula foi de $27,5 \%$ e do hipocótilo de $10 \%$. Esses resultados, quando comparados aos efeitos promovidos pelas substâncias isoladamente, apontam tendência de aumento na atividade inibitória, sendo em alguns casos (efeitos sobre o desenvolvimento da radícula da espécie malícia) de quase $100 \%$. Entretanto, em valores absolutos, a atividade das duas substâncias em associação não ultrapassou o valor de $27,5 \%$ de inibição, o que limita essa possibilidade.

Efeitos semelhantes aos do presente traba1ho são encontrados na literatura (Vokou et al., 2003; Einhellig, 1995; Weidenhamer et al., 1994), nos quais as substâncias químicas, quando em combinação aos pares, tendem a evidenciar maior potencial inibitório do que quando testadas isoladamente. Muitos autores atribuem esses efeitos à existência de sinergismo entre as substâncias testadas aos pares; entretanto, para os resultados deste trabalho, o termo "ação aditiva" é mais apropriado, pois a concentração, no caso das substâncias analisadas em combinação (em par), dobra em relação àquela de cada substância isoladamente.

A atividade biológica de um dado aleloquímico depende tanto da concentração como do limite de resposta da espécie afetada. O limite de inibição para uma substância não é constante, porém está intimamente relacionado à sensibilidade da espécie receptora, aos processos da planta e às condições ambientais. No presente trabalho, o fator concentração foi decisivo para a magnitude das inibições obtidas, com exceção dos efeitos observados sobre o desenvolvimento do hipocótilo. No mesmo sentido, as plantas daninhas utilizadas com o receptoras apresentaram diferentes sensibilidades aos dois semioquímicos testados, sendo, no geral, a espécie malícia mais sensivel aos efeitos.

As duas substâncias isoladas do fungo Pestalotiopsis guepinii foram obtidas a partir do extrato bruto hexânico. Entretanto, ao comparar os efeitos inibitórios efetivados pelo extrato bruto sobre a germinação de sementes (Tabela 1) e sobre o desenvolvimento da radícula (Tabela 2 ) e do hipocótilo (Tabela 3), observa-se que a intensidade dos efeitos do extrato bruto foi maior que a daqueles promovidos pelas duas substâncias isoladamente ou ao par, indicando que muito provavelmente outros metabólitos estejam associados aos efeitos dos extratos brutos que não as duas substâncias isoladas e identificadas. Dessa forma, é de se esperar que outros metabólitos mais efetivos em relação à inibição da germinação de sementes e do desenvolvimento da radícula e do hipocótilo possam estar presentes no extrato bruto hexânico, os quais devem explicar melhor a magnitude dos efeitos promovidos pelo extrato bruto.

\section{LITERATURA CITADA}

CARVALHO, J. C. T. et al. Anti-inflammatory activity of flavone and some of its derivatives of Virola michellii Heckel. J. Ethnopharmacol., v. 64, p. 173-177, 1999.

CASTELLANI, A. Viability of mold culture of fungi in destiled water. J. Trop. Med. Hyg., v. 42, p. 225, 1939. 
EINHELLIG, F. A. Allelopathy: current status and future goals. In: INDERJT, DAKSHINI, K. M. M.; EINHELLI, F. A. Allelopathy: organisms, processes and applications. Washington: 1995. p. 1-24. (ACS. Symposium Series).

FAHEY, J. W. Endophytic Bacteria four the delivery of agrochemicals to plants. In: CUTLER, H. O. (Ed.). Biologically active natural producs. Potential use in agriculture. Washington: American chemical society, 1988. p. $120-128$.

GOTTLIEB, O. R.; YOSHIDA, M. Lignóides-Com Atenção Especial à Química das Neolignanas. Quím. Nova, v. 7, p. $250-273,1984$

HALLMANN, J.; SIKORA, R. A. Toxicity of fungal endophyte secondary metabolites to plant parasitic nematodes and soil - borne plant pathogenic fungi. European J. Plant Pathology, v. 102, p. 155-162, 1996.

MARINHO, A. M. R. et al. Biologically active polyketids produced by Penicillium janthinellum isolated as an biologically endophytic fungus from fruits of Melia azedarach. J. Braz. Chem. Soc., v. 16, p. 280-283, 2005 a.

MARINHO, A. M. R. et al. C25 steroid produced by Penicillium janthinellum, a fungus isolated from fruits of Melia azedarach. J. Braz. Chem. Soc., v. 16, p. 1542-1546, 2005b.

MURRAY, F. R.; LATCH, G. C. M.; SCOTT, D. B. Surrogate transformation of perennial ryegrass Lolium perenne, using genetically modified Acremonium endophyte Mol. General Gen., v. 233, p. 1-9, 1992

PEREIRA, J. O. Fungos endofíticos dos hospedeiros tropicais. 1993. $104 \mathrm{f}$. Tese (Doutorado em Ciências), Escola Superior de Agricultura Luiz de Queiroz, Piracicaba, 1993.

PETRINI, O. Fungal endophyte of three leaves. In: ANDREWS, J.; HIRANO, S. S (Eds.). Microbial Ecology of Leaves. New York. Springer Verlag. p. 179-197, 1991

SANTOS, L. S. et al. Constituents from the leaves of Virola michellii. Fitoterapia, v. 67, n. 6, p. 555-556, 1996.

SANTOS, L. S. et al. Allelochemicals isolated from the leaves of Virola michelli Heckel. Allelopathy J., v 20, n. 1, p. $235-243,2007$.
SANTOS, R. M. G. Metabolismo secundários de fungos endofíticos associados a Melia azedarach. 2001. 311 p. Tese (Doutorado em Química) - Universidade Federal de São Carlos, São Carlos, 2001.

SHIMADA, A. et al. Hydroxysulochrin, a tea pollen growth inhibitor from the fungus Aureobasidium sp. Biosc.

Biotechnol. Biochem., v. 67, n. 2, p. 442-444, 2003.

SOUZA, A. Q. L. et al. Atividade antimicrobiana de fungos endofíticos isolados de plantas tóxicas da amazônia: Palicourea longiflora (aubl) Rich e Strychnos cogens Bentham. Acta Amazônica, v. 34, n. 2, p. 185-195, 2004.

SOUZA FILHO, A. P. S.; ALVES, S. M. Alelopatia: princípios básicos e aspectos gerais. Belém: Embrapa Amazônia Oriental. 2002. 260 p.

SOUZA FILHO, A. P. S.; BORGES, F. C.; SANTOS, L. S. Análise comparativa dos efeitos alelopáticos das substâncias químicas titonina e titonina acetilada. Planta Daninha, v. 24 , n. 2 , p. $205-210,2006$.

SOUZA FILHO, A. P. S.; DUTRA, S.; SILVA, M. A. M. M. Métodos de superação da dormência de sementes de plantas daninhas de pastagens cultivadas da amazônia. Planta Daninha, v. 16, n. 1, p. 3-11, 1998.

STROBEL, G. et al. Isopestacin, an isobenzofuranone from Pestalotiopsis microspora, possessing antifungal and antioxidant activities. Phytochemistry, v. 60, p. 179-183, 2002.

SUMMERELL, B. et al. Pestalotiopsis guepinii, a Taxolproducing Endophyte of the Wollemi Pine, Wollemia nobilis. Austr. J. Bot., v. 45, n. 6, p. 1073-1082, 1998.

VOKOU, D. et al. Effects of monoterpenoids, acting alone or in pairs, on seed germination and subsequent seedling growth. J. Chem. Ecol., v. 29, n. 10, p. 2281-2301, 2003.

VOLKSCH, B.; ULLRICH, M.; FRYTSCHE, W. Identification and population dynamics of bacteria in leaf spots of soybean. Mycrobial Ecol., v. 24, p. 305-311, 1992.

WEIDENHAMER, J. D. et al. Allelopathic potential of menthofuran monoterpenes from Calamuntha ashei. J. Chem. Ecol., v. 20, p. 3345-3359, 1994. 